\title{
The Stability of Angiotensin I Formed at Room Temperature in the Presence of Ethylenediaminetetraacetate to Subsequent Incubation at $37^{\circ} \mathrm{C}$
}

\author{
By J. E. Roulston, MA, PhD, MRSC \\ University Department of Clinical Chemistry \\ Bella Sanger and C. G. Wathen, BSc, MRCP \\ University Department of Medicine \\ The Royal Infirmary Edinburgh, U.K.
}

(Received January 14/May 16, 1983)

Summary: It has been reported that plasma renin activity values obtained from samples containing ethylenediaminetetraacetate (EDTA) and which have been allowed to remain at room temperature for 24-48 hours prior to incubation and assay are spuriously low. Since plasma renin activity is often measured in specialised centres, considerable time delays in sample transit may be difficult to avoid. We, therefore, investigated these findings using plasma samples kept at room temperature for varying times and subsequently incubated at $37^{\circ} \mathrm{C}$.

From these studies we conclude that plasma renin activity is not significantly affected by pre-incubation at room temperature for periods up to 48 hours. However, the precision of the assay is likely to be poorer in specimens pre-incubated at room temperature. These results are supported by the finding that there is no loss of angiotensin I upon incubation and assay of samples containing pepstatin A.

Die Stabilität von Angiotensin I, gebildet bei Raumtemperatur in Gegenwart von Ethylendiamintetraacetat, in Plasma für die nachfolgende Inkubation bei $37^{\circ} \mathrm{C}$

Zusammenfasșungăg: Es wurde berichtet, daß Reninaktivitätswerte im Plasma von Proben, die EDTA enthielten und vor Inkubation ünd Messung $24=48 \mathrm{~h}$ bei Raumtemperatur standen, fälschlich zu niedrig sind. Da die Reninaktivität im Plasma oft in spezialisierten Zentren bestimmt wird, lassen sich beachtliche Verzögerungen im Probendurchsatz kaum vermeiden. Wir haben deshalb diese Befunde an Plasmaproben, die für verschiedene Zeiten bei Raumtemperatur gehalten und anschließend bei $37^{\circ} \mathrm{C}$ inkubiert wurden, nachuntersucht.

Wir schließèn aus diesen Untersuchungen, daß die Reninaktivität im Plasma durch Vorinkubation bei Raumtemperatự bị zu $48 \mathrm{~h}$ nicht signifikant beeinflußt wird. Die Präzision der Bestimmung in solchen Proben scheint jedoch schlechter zu sein. Diese Ergebnisse werden durch den Befund unterstützt, daß kein Verlust von Angiotensin nach Inkubation und Messung von Proben, die Pepstatin A enthalten, auftritt.

\section{Introduction}

Plasma renin activity is a widely used in vitro assessment of the activity of the renin-angiotensin system. Blood samples are collected into an anticoagulant and plasma separated and stored at $-20^{\circ} \mathrm{C}$ prior to a two-stage assay. In the first stage, each plasma sample is buffered, mixed with angiotensin-converting enzyme inhibitors and subdivided into two portions, one of which is kept either on ice or in the deep freeze at $-20^{\circ} \mathrm{C}$ and the other is incubated at $37^{\circ} \mathrm{C}$ 
for 1-3 hours to generate angiotensin I. In the second stage, aliquots of both portions of the sample are assayed for angiotensin I concentration. The difference in concentration between the portions is expressed as an angiotensin I generation rate, the plasma renin activity.

Ethylenediaminetetraacetate (EDTA) is the most widely used anticoagulant for samples for plasma renin activity assay. It has an inhibitory effect upon the converting enzyme $(1,2)$, whereas lithium heparinate has been reported to inhibit renin (3) thereby reducing the production of angiotensin I in vitro; although this finding is not supported by studies with hog renin (4), or human renin in the presence of low heparin concentrations (5).

It has recently been reported that the use of EDTA as the anticoagulant may lead to falsely low plasma renin activity values if plasma samples are allowed to stand at room temperature for 24-48 hours (5). This is a cause for concern owing to the widespread use of EDTA in such assays, and the possibility, despite stringent sample-handling protocols, that plasma renin activity samples may attain room temperature in transit from the clinicians to the laboratories. This possibility is made all the more likely because plasma renin activity assays still tend to be offered only by a few centres each catering for a wide area.

The authors suggested (5) that this apparent fall in plasma renin activity could be due to the angiotensin I which builds up at room temperature being unstable upon subsequent incubation at $37^{\circ} \mathrm{C}$. This would mean that the immunoassay of the unincubated angiotensin I blank would overestimate the preformed angiotensin I concentration which remained post-incubation. This would reduce the 'net' generation value and, thereby, the plasma renin activity. As yet, there is no direct evidence to support this.

In this study we investigated this phenomenon using a plasma which had been stored in individual portions at $-20^{\circ} \mathrm{C}$ in EDTA. Samples were thawed at intervals and allowed to "pre-incubate" at room temperature for up to 48 hours. They were then incubated at $37^{\circ} \mathrm{C}$ for 1 or 3 hours and immunoassayed to estimate their apparent plasma renin activity. In addition pepstatin $A$, an inhibitor of renin (6), was added to two samples which had been pre-incubated at room temperature for 48 hours immediately before incubation at $37^{\circ} \mathrm{C}$. If preformed angioten$\sin \mathrm{I}$ was unstable at $37^{\circ} \mathrm{C}$, then a "negative generation" would be seen; that is, an overall loss of angiotensin I.

\section{Materials and Methods}

\section{Assay procedures}

Angiotensin I was generated in citrate-buffered plasma in the presence of EDTA, 8-hydroxyquinoline and phenylmethylsulphonylfluoride, as described previously (7), for one and for 3 hours. Angiotensin blanks were kept at $-20^{\circ} \mathrm{C}$ during the incubation period since storage at $-5^{\circ} \mathrm{C}$ to $+4^{\circ} \mathrm{C}$ cán activate pro-renin and this "cryo-activatable" fraction may greatly exceed the active enzyme concentration (8). $25-100 \mu$ l aliquots of samples were estimated by radioimmunoassay using a 24 hour incubation at $4^{\circ} \mathrm{C}$ followed by a charcoal separation of bound and free fractions.

\section{Samples}

$250 \mathrm{ml}$ of blood were collected from a normotensive supine volunteer, into tubes containing EDTA ( $2.5 \mathrm{~g} / \mathrm{l}$ blood). After centrifugation, plasma was stored at $=20^{\circ} \mathrm{C}$ in one ml portions. Seven portions were thawed 48 hours prior to their incubation, 5 were thawed 24 hours before incubation, and 5 were thawed and brought to room temperature immediately before incubation. To 2 of the samples from the first group, $20 \mu$ lof pepstatin A (Sigma U.K., Poole, Dorset) in $9 \mathrm{~g} / \mathrm{l}$ saline solution (approximately $5 \mu \mathrm{g} /$ $20 \mu \mathrm{l})$ were added to inhibit renin during the incubation at $37^{\circ} \mathrm{C}$.

\section{Data analyses}

For each period of pre-incubation ( 0,24 and 48 hours) the results of the analysis for angiotensin concentration in the 5 tubes at 0,1 and 3 hours were available.

Regression analysis methods were used to model the changes in angiotensin concentration with incubation time. The final model chosen to fit the data was

$$
A=K_{n}+b_{1} t_{(0-1)}+b_{2} t_{(1-3)}+\varepsilon
$$

where

$$
\begin{aligned}
& \text { A }=\text { angiotensin concentration } \\
& \mathrm{K}_{\mathrm{n}}=\text { intercept for sample } \mathrm{n} \\
& \mathrm{b}_{1}=\text { plasma renin activity }(0-1 \text { hour) } \\
& \mathrm{b}_{2}=\text { plasma renin activity }(1-3 \text { hours) } \\
& \mathrm{t}_{(0-1)}=\text { incubation time before } 1 \text { hour } \\
& \mathrm{t}_{(1-3)}=\text { incubation time after } 1 \text { hour } \\
& \varepsilon=\text { residual from fitted model. }
\end{aligned}
$$

For each pre-incubation time the constants $b_{1}, b_{2}, K_{1} \ldots K_{5}$ can be estimated from the data, as can the average standard deviation of the residuals $(\varepsilon)$. The standard deviation of the residuals gives a measure of the analytical errors of the method. The average $\mathrm{K}$ value estimates the mean angiotensin activity after the pre-incubation. The between-sample variance of the $5 \mathrm{~K}$ values (corrected for analytical error by subtracting $1 / 5$ of the residual variance) measures the variation in pre-incubation activity between the set of 5 one $\mathrm{ml}$ portions.

Statistical significance was estimated by the standard $t$ and $F$ tests of linear regression analysis (see, for example, Draper \&. Smith (9)).

\section{Results}

The estimated plasma renin activity values are shown in table 1 and indicate no significant differences between the groups of samples pre-incubated for 0,24 or 48 hours. This result was obtained whether the samples were incubated at $37^{\circ} \mathrm{C}$ for 1 or for 3 hours. 
Tab. 1. Plasma renin activity and residual errors.

\begin{tabular}{llll}
\hline $\begin{array}{l}\text { Pre- } \\
\text { incubation } \\
\text { time } \\
\text { (h) }\end{array}$ & $\begin{array}{l}\mathrm{b}_{1} \\
0-1 \mathrm{~h}(\mathrm{s.e.})\end{array}$ & $\begin{array}{l}\mathrm{b}_{2} \\
1-3 \mathrm{~h}(\mathrm{s.e.})\end{array}$ & $\begin{array}{l}\text { Residual* } \\
\text { s.d. }\end{array}$ \\
\hline 48 & $\mu \mathrm{g} / \mathrm{h} \cdot 1$ & $\mu \mathrm{g} / \mathrm{h} \cdot 1$ & $\mu \mathrm{g} / 1$ \\
\hline 24 & $9.2(0.8)$ & $5.9(0.4)$ & $1.31^{\mathrm{a}}$ \\
0 & $8.6 \cdot(0.9)$ & $6.4(0.4)$ & $1.35^{\mathrm{b}}$ \\
& $7.8(0.3)$ & $6.0(0.2)$ & 0.53 \\
\hline
\end{tabular}

* Each s.d. is based on 8 degrees of freedom

a Significantly greater than value at zero pre-incubation $p<0.02$

b Significantly greater than value at zero pre-incubation $p<0.01$

The plasma renin activity values obtained from the aliquots which underwent one hour incubation were consistently slightly higher than the values from the aliquots which underwent three hours incubation at $37^{\circ} \mathrm{C}$. In two of the three groups, 48 hour pre-incubation and no pre-incubation, this difference was statistically significant $(p<0.01$ and $<0.05$ respectively).

Table 1 also gives the residual standard deviations at various pre-incubation times. Their squares (variances) were compared with F-tests. There is a significant increase in the experimental (analytical) error with pre-incubation for 24 or 48 hours $(p<0.01$ ) compared with no pre-incubation, but there is no significant difference between the effects at 24 and 48 hours.

Table 2 shows the mean activity after pre-incubation and the differences between individual samples. The between sample standard deviations are corrected for analytical errors. There is a significant increase in variance due to "sample effects" with a preincubation time of 24 hours and a further significant increase at 48 hoürs. The value of zero for sample s. d. at zero hour pre-incubation is the result of the residual variance divided by $5(=n)$ being greater than the variance due to the $K$ values.

Tab. 2. Mean angiotensin activity after pree-incubation and its between-sample variability.

\begin{tabular}{llll}
\hline $\begin{array}{l}\text { Preincubation } \\
\text { time }\end{array}$ & $\begin{array}{l}\text { Mean activity } \\
(\mathrm{K})\end{array}$ & $\begin{array}{l}\text { Between } \\
\text { sample s.d. }\end{array}$ & $\begin{array}{l}\text { Degrees } \\
\text { of } \\
\text { freedom }\end{array}$ \\
(h) & $\mu \mathrm{g} / 1$ & $\mu \mathrm{g} / \mathrm{l}$ & \\
\hline 48 & 21.0 & 5.1 & 4 \\
24 & 17.3 & 0.9 & 4 \\
0 & 0.76 & 0 & 4 \\
\hline
\end{tabular}

Table 3 lists the coefficients of variation of the mean plasma renin activity values obtained at each incubation and pre-incubation time.

Tab. 3. Coefficient of variation of plasma renin activity data obtained at various pre-incubation and incubation times.

Pre-incubation time (h)

$48 \quad 24$

0

Incubation time (h) Coefficient of variation (\%)

\begin{tabular}{rrrr}
\hline 1 & 12.9 & 13.7 & 9.1 \\
3 & 12.3 & 9.8 & 2.6 \\
\hline
\end{tabular}

In the samples to which pepstatin A had been added, the angiotensin I blanks yielded similar values to those obtained from the 48-hour pre-incubated group. Incubation of these samples for 1 and 3 hours at $37^{\circ} \mathrm{C}$ produced only small rises in total angiotensin I concentration. All of the mean experimental results are displayed in figure 1.

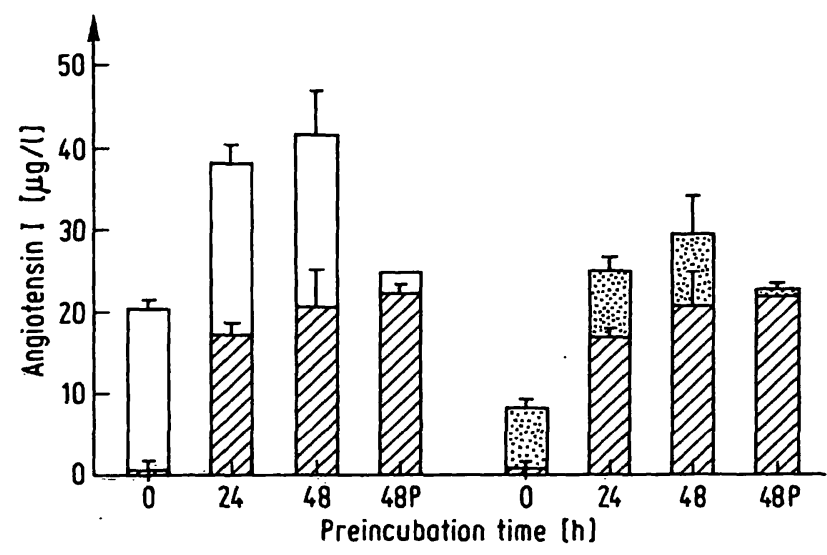

Fig. 1. Angiotensin I production under different conditions of pre-incubation and incubation times. $48 \mathrm{P}$ indicates that pepstatin $A$ was added to these samples after the pre-incubation period.

Angiotensin I produced in $3 \mathrm{~h}$ at $37^{\circ}( \pm 1 \mathrm{SD}$ )

Angiotensin I produced in $1 \mathrm{~h}$ at $37^{\circ}( \pm 1 \mathrm{SD}$ )

Angiotensin I blank ( $\pm 1 \mathrm{SD}$ )

\section{Discussion}

These results indicate that samples collected into tubes containing EDTA may be assayed after storage at room temperature for up to 48 hours without compromising the accuracy of the plasma renin activity estimation. Incubation times of one and three hours were employed and yielded similar results, 
showing no significant difference in mean plasma renin activity with respect to preincubation time.

The decreased analytical precision seen with increasing preincubation time (tab. 1) may be explained by the fact that these samples contained high concentrations of angiotensin I and were interpolated from a part of the standard curve where the slope was decreasing markedly.

The plasma renin activity values obtained from the one hour generated samples are consistently slightly higher than their three hour generated counterparts. This is likely to be a reflection of the temperature variations in the samples at the beginning and end of the incubation period representing a more significant fraction of the total incubation time. The transfer time at the end of the incubation period in which the samples are frozen is a significantly greater incremental addition to the one hour incubation time than to the three hour incubation. Incomplete angiotensinase inhibition could also account for such changes, but in this system has been shown not to be significant (10). Another possible explanation, a change in reaction kinetics owing to substrate depletion over the longer time of incubation, is not considered likely. Firstly, if substrate depletion were a problem, this would be expected to show in the 48-hour pre-incubated group, manifesting as a reduced plasma renin activity with respect to the 24-hour and unpre-incubated groups, but there was no sign of this. Secondly, Stockigt \& Hewett (5) found no appreciable loss in plasma renin substrate (angiotensinogen) in their experiments conducted over similar preincubation times and three hour incubation times. Thirdly, there is evidence that, in this assay system, linearity of angiotensin I production is continued to much higher levels than those observed here (11). The possibility of substrate depletion for individual samples, however, still remains. Usually an abnormally high blank value will be indicative of prolonged preincubation.

The results in table 2 show clearly that angiotensin is formed during the period of pre-incubation and that there are considerable between-sample differences in the amount of angiotensin formed in a given pre- incubation period. However, these differences do not affect the accuracy of the plasma renin activity measurement since the angiotensin formed during pre-incubation is subtracted, as a 'blank', from that formed at the end of the assay incubation at $37^{\circ} \mathrm{C}$.

The results obtained from the samplés to which pepstatin $\mathrm{A}$ had been added support the conclusion that preformed angiotensin $I$ is not inherently unstable when the temperature is raised to $37^{\circ} \mathrm{C}$. The angiotensin blanks do not differ from those of the uninhibited 48 hour samples, and there is a small rise in total angiotensin I concentration with subsequent incubation at $37^{\circ} \mathrm{C}$. Pepstatin A does not completely inhibit renin (12) and this residual activity would account for the rises seen upon incubation. However, any significant breakdown of the preformed angiotensin I during the incubation would have yielded a net loss of angiotensin I in the tube; this did not occur.

These results do not agree with the findings of Stockigt \& Hewett (5). It is possible that their boiling of the samples to end the incubation, a procedure we did not adopt, may selectively destroy preformed angiotensin.

We conclude that samples collected into tubes containing EDTA may be assayed for plasma renin activity up to 48 hours after thawing without any apparent change in the result. The only problem is a loss of precision which may arise for the reasons discussed earlier, and, for this reason, results from samples which have been in a "pre-incubation" state may be compromised; particulầrly extremely lợ plasma renin activity values. One possible alternative would be to collect specimens into a non-inhibit= ing anticoagulant (13); this would not cause blanks to increase and, therefore, precision should not be affected.

\section{Acknowledgements}

The authors would like to thank Dr. A. F. Smith for his advice, Ms. G. M. Raab for statistical analyses, and Mrs. E. Ward for preparing the manuscript. 


\section{References}

1. Cushman, D. W. \& Cheung, H. S. (1971) Biochem. Pharmacol. $20,1637-1648$.

2. Huggins, C. G., Corcoran, R. J., Gordon, J. S., Henry, H. W. \& John, J. P. (1970) Circ. Res. 26-27, Suppl. I, 93-101.

3. Sealey, J. E., Gerten, J. N., Ledingham, J. G. G. \& Laragh, J. H. (1967) J. Clin. Endocrinol. 27, 699-705.

4. Churchill, P. C., Lyons, H. J., Murano, G. \& McDonald, F. D. (1978) Nephron 22, 113-116.

5. Stockigt, J. R. \& Hewett, M. J. (1981) Pathology 13, 603608.

6. Gross, F., Lazar, J. \& Orth, H. (1972) Science 175, 656.

7. Roulston, J. E. \& MacGregor, G. A. (1978) Clin. Chim. Acta $88,45-48$.

8. Sealey, J. E., Moon, C., Laragh, J. H. \& Atlas, S. A. (1977) Circ. Res. 40, Suppl. I, 41-45.

9. Draper, N. R. \& Smith, H. (1980) Applied regression analysis, 2nd edition. Wiley, New York.

10. Roulston, J. E. (1981) PhD. thesis (London) Chapter 11, 171-222.

11. Roulston, J. E., MacGregor, G. A., Adam, T. \& Markandu, N. D. (1978) Ann. Clin. Biochem. 15, 250-252.

12. McKown, M. M., Workman, R. J. \& Gregerman, R. I. (1974) J. Biol. Chem. 249, 7770-7774.

13. Roulston, J. E., Wathen, C. G., Sanger, B. \& Muir, A. L. (1983) Ann. Clin. Biochem. 20, 217-219.

J. E. Roulston, MA, PhD, MRSC

Dept. of Clinical Chemistry

The Royal Infirmary

Edinburgh

EH3 9YW 
